\title{
STRUCTURAL ANALYSIS AS A SUPPORTING METHOD FOR THE RESEARCH OF MEDIEVAL BRICK ARCHITECTURE
}

\author{
PIOTR SAMÓL ${ }^{1 *}$, PIOTR IWICKI ${ }^{2}$ AND JAROSŁAW PRZEWŁÓCKI ${ }^{3}$ \\ ${ }^{1}$ Gdańsk University of Technology, Faculty of Architecture, \\ Narutowicza St. 11/12, 80-230 Gdańsk \\ e-mail: piosamol@pg.edu.pl (*corresponding author) \\ ${ }^{2}$ Gdańsk University of Technology, Faculty of Civil and Environmental Engineering, \\ Narutowicza St. 11/12, 80-288 Gdańsk \\ email: piotr.iwicki@pg.edu.pl \\ ${ }^{3}$ Gdańsk University of Technology, Faculty of Architecture, \\ Narutowicza St. 11/12, 80-230 Gdańsk \\ e-mail: jprzew@pg.edu.pl
}

Keywords: Historical Structure, Masonry, Brick Architecture, Numerical Analysis, Architectural Investigation

\begin{abstract}
Chronology of brick historical buildings might be established much more precisely than the chronology of stone ones due to the architectural and metrical analysis of bricks, mortars and brickworks. Comparison of historical sources allows to reconstruct the previous stages of constructing monuments. Causations between transformations and developments of monuments are usually interpreted as the results of artistic or ideological influence rather than pragmatic decisions. Such explanations neglect, however, the impact of structural disasters and imperfections. Experience, delivered by the previous erroneous solutions or failures, undoubtedly influenced the further development of architecture.

In this paper the authors present how numerical modelling and structural analysis of complex historical brick buildings and different stages of their alterations might be used as a supporting method for the research of their history. Consequently, modern numerical tools for structural analysis can also be useful in investigating of the process of creating architectural solutions [1]. Because more accurate historical analyses belong to the qualitative research, it is not possible to examine very wide group of different monuments. Therefore the authors chose for that purpose the homogeneous group of the mendicant orders' medieval churches in the former State of Teutonic Order in Prussia, which have been the subject of authors' in situ research since 2009 [2]. This group is thought to be representative for the medieval techniques of the brick architecture in northern Europe and Baltic Sea Region.

The aim of this research is to find out whether structural analysis might be carried out in a historical building in which consecutive transformations partially erased its original form (reconstructed on the base of the architectural and archaeological research)? A positive answer to that question allows to put another one - about whether the numerical modelling of the structure of monument might give some additional information on its history? The results
\end{abstract}


of described research might give a new tool for conservators, architects, archaeologists and engineers in their research and other conducting works.

\section{INTRODUCTION}

Medieval brick structures are the subject of research in many different fields of art, humanities and science including history, archaeology, architecture and engineering. Despite the fact that such types of research have been continuously conducted and developed, the combined interdisciplinary studies on historic buildings are rare and usually limited to the most significant ones. It is caused by financial reasons as well as different state of art in particular disciplines. In most typical cases, the history of a monument was elaborated without any archaeological or architectural examines, which - in turn - did not include the structural analysis. Moreover, because of the development of no-destructive methods of the structural analysis the current state of structure might be examined without intervention in the historical substance of monument. Undoubted benefits for conservational values give, however, highly limited support in expanding the knowledge about the history of the monument. What is more, historians very rarely used the results of research in situ as a primary source although they might allow to reinterpret information gained from the written sources.

The most recent research on using advanced digital technologies (like BIM, FEM) in the heritage preservation focuses on the analyzing the current state of particular structures or the protection of cultural structures. The reviews have been presented in analysis, distinct elenen used most often. The FE
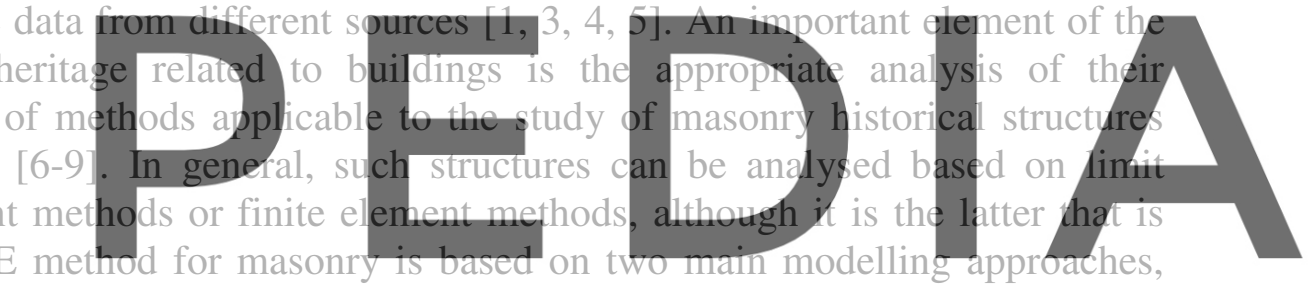
namely, Micro-modelling and Macro-modelling [8]. In the first case, the units and mortar are

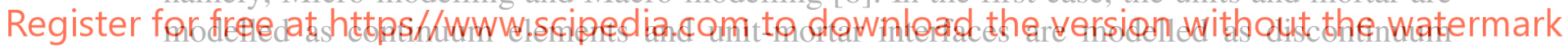

elements. In the latter, the masonry is considered a homogenous material with no distinguishing between units and mortar. Some interesting examples of applications of finite element methods to analyze historical masonry structures are given, among other, in [7-8, 10]. Recently, the damage model based on plastic degradation, proposed by Lubliner [11], is increasingly used in modelling historical masonry structures [12-14]. Numerical analysis of masonry should take into account not only its above-ground parts, i.e. walls, pilars, ceilings or vaults, but also foundations. Unfortunately, there are few comprehensive studies devoted to foundations of historical buildings $[15,16]$. Most of the papers concern the diagnostics and maintenance of specific buildings foundations and case studies. Various aspects of the history of foundation engineering, with particular focus on its development, techniques applied, materials used and stabilization methods, are described in the latter. Numerical analysis of stone foundation by the finite element method is given in $[17,18]$. In the latter, the damage model based on plastic degradation was applied.

The aim of this paper is to present how structural analysis might be used to supply the architectural investigations and give a feedback to the interdisciplinary studies of historic 
monuments. This thesis is to be illustrated on the examples of mendicant churches from the former state of Teutonic Knights in Prussia.

\section{METHODOLOGY}

Architectural investigation was carried out with computer support - inventories were supported by photogrammetry, inventory drawings and reconstruction drawings that had been processed using AutoCAD programs. Although the historical research includes mostly traditional method of analyzing the monuments, using the numerical methods allows to verify particular reconstructions proposed on the basis of architectural research. Such a verification has not been proposed yet. Therefore, the architectural research will be supplemented in selected facilities with engineering research. The authors of this paper selected particular objects, in which state of art allowed to compare the historical, architectural and engineering research. The archival and library queries were conducted in State Archives in Gdańsk and Elblag (Poland) and the Images Archive of Herder Institute in Marburg. In the next step, the results of historical studies were confronted with the architectural investigations which methodology is described below. Eventually, the numerical analyzes for subsequent stages of construction were performed.

Architectural research presented in this paper is based on destructive and non-destructive examines that have been conducted in situ since 2010. The aim of that research was to acknowledge the stratigraphy of the historic building. It was completed thanks to accomplishing five following tasks. 1.Performing architectural and conservation in ventory, Comparing the result archaeological surveys) measurement (about 20 mortar, 4. Relative dati on historical research ar
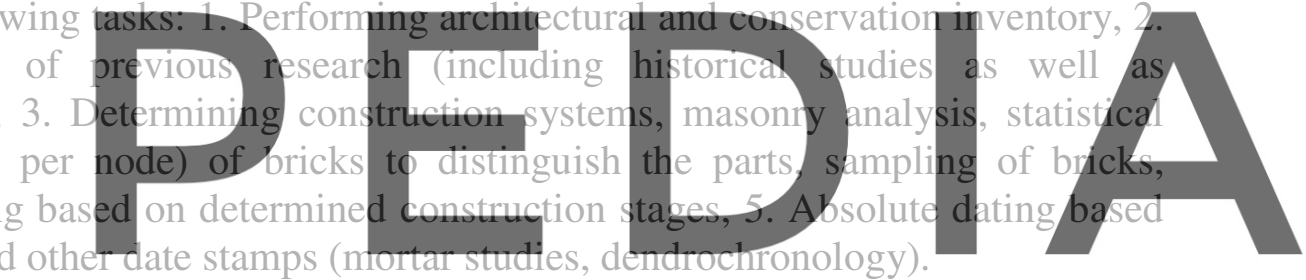

Described research was possible to conduct because of the state of survived medieval brick

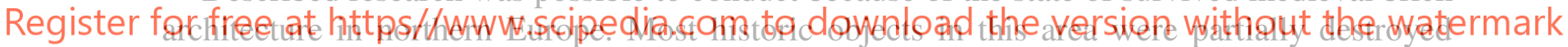
during the Second World War, which caused huge wastes for cultural heritage but also gave an opportunity to recognize the structure of buildings. In case of the church in Elblagg, almost whole authentic uncovered brick walls were accessible for the research team. Therefore, it was possible to establish over 200 nodes and conduct a very precise analysis of its architectural structure. Those works bring the evidence basis for the further examines - the structural analysis of the following stages of construction. This will allow verifying the hypothetical reconstructions proposed on the basis of architectural research. Because such a study requires comparing the results of architectural investigation and structural analysis for each stage of construction, they will be described in two following parts, but the relations between them will be summarized together.

\section{RESULTS OF ARCHITECTURAL INVESTIGATION}

Dominican church of Our Virgin Lady in Elbląg (Elbing) is the oldest brick building within the territory of the former state of Teutonic Knights in Prussia. The lower part of the east choir was elevated after 1246, which was connected to the foundation of the first brickyard at the southern coast of Baltic Sea that was confirmed in historical written sources $[2,19]$. The 
current research, that was conducted in years 2010-2019, allowed to recognize the several stages of its construction which were unknown before. The stratigraphy of the church is presented at the Fig 1.
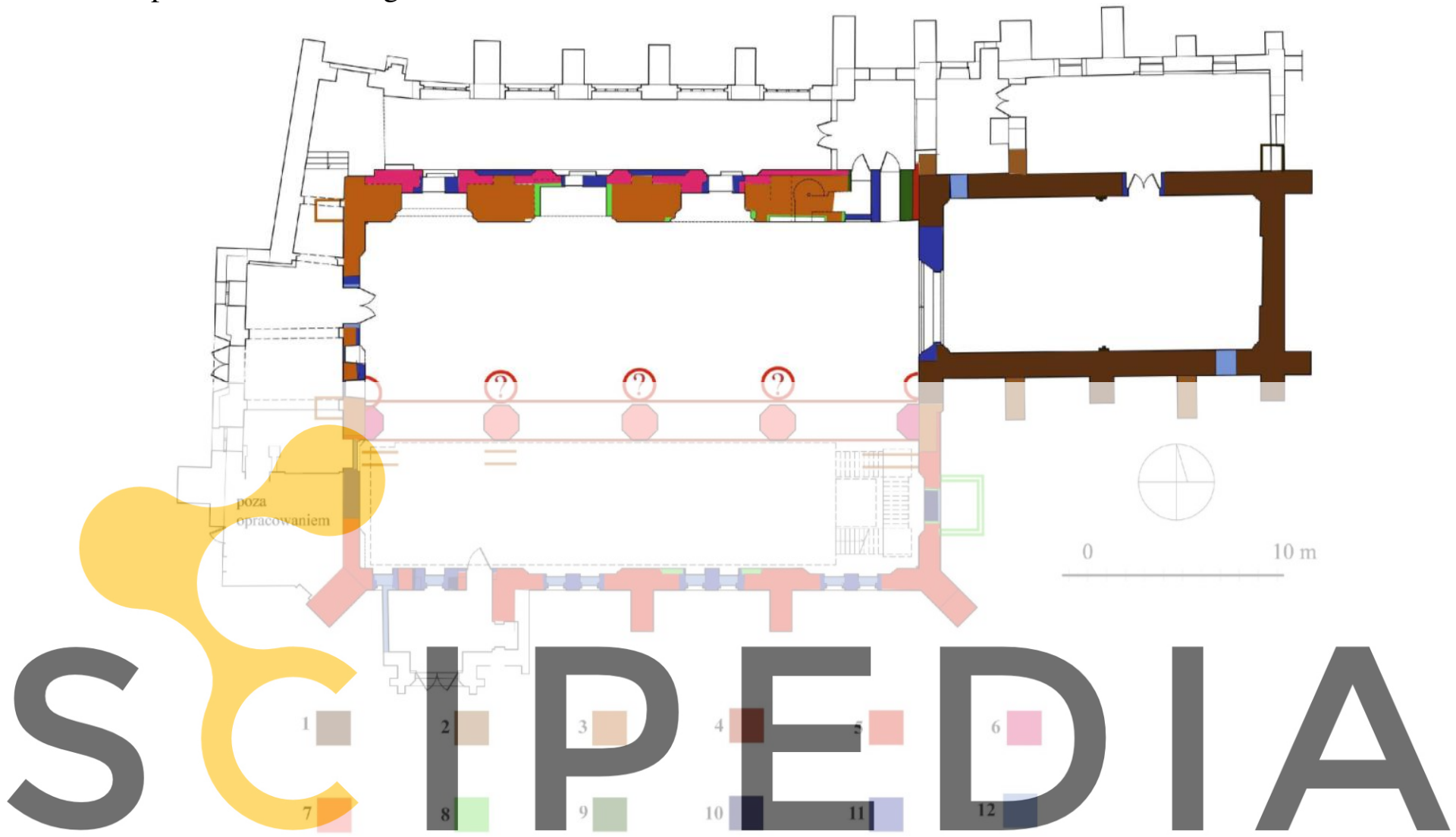

Register figure 1: Plan of the church of Our Virgin Lady in Elblag. The results of architectural research [2]: 1- 1246-c. the $14^{\text {th }}$ century, 6 - 2nd half of the $14^{\text {th }}$ century, 7 - around $1470-1504$ ?, 8 - 2 nd half of the $16^{\text {th }}$ century - early $17^{\text {th }}$ century, $9-17^{\text {th }}$ - early 18 th century, $10-1$ st half of the $19^{\text {th }}$ c., $11-2$ nd half of the $19^{\text {th }}$ c. $-1930,12$ after 1960.

Multiple spatial transformations in the Middle Ages were typical for the mendicant orders' architecture in large merchant cities like Elbląg, (as well as Gdańsk or Lübeck). The first choir was enhanced twice ca. 1275 and then, at the end of the $13^{\text {th }}$ century. The archaeological surveys from 1959 and 2008 [20,21] gave information about the construction of foundations of the church and the rests of previous versions of the rebuilt nave. Those results had not been interpreted however by the excavators because they did not conduct the parallel examines on architecture. The corpus was erected as a single nave church (around 1300) and extended later to a symmetrical two-nave hall (around 1320). The central row of circular pillars, that separated two naves, was situated then on the stone bases, which were later reused in fundaments of the octagonal pillars. The choir screen and vaults above the naves were probably set at the same time. Although, during next two centuries, the church was enhanced several times, the external plan of the building was not transformed. Therefore the analysis of the eastern wall of the nave is crucial for aknowleding the history of the monument (Fig 2.). 


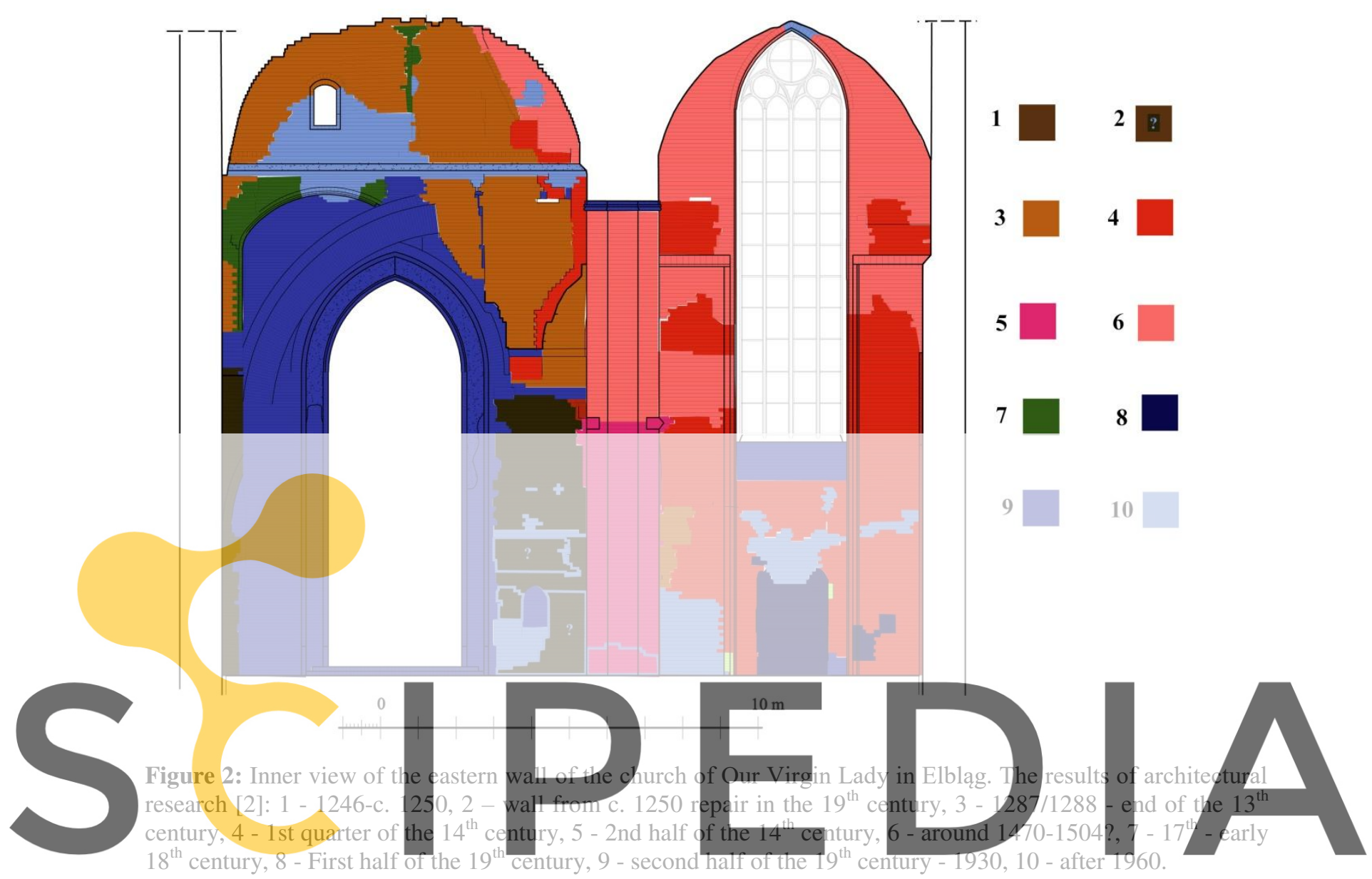

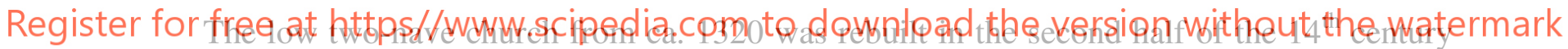

\section{(Fig. 3a). Because of changing architectural trends the friars wanted to erect the nave on the}

axis of the east choir. However, such decision caused demolition of the circular pillars and then replacing them by the octagonal ones. The new construction needed better foundations than the previous one, therefore the row of octagonal pillars was not situated exactly in the place of circular pillars but around $1.5 \mathrm{~m}$ to the south. As a consequence, the corpus lost its symmetrical plan. The two naves got then different height and width, though they were covered by the one roof. Such a construction used to be called a "pseudobasilica" [22]. Described action is proved by the evidence such as the shape of the demolished vaults, which is situated on the eastern wall, between the current pillar and the chancel arch.

After the Thirteen Years War (1454-1466) the church was enlarged once again. The southern nave was enhanced to the height of the northern one. At the end of the $15^{\text {th }}$ century the western and eastern walls got a new gable (partially reconstructed after the Second World War). The new hybrid crystal-netted vaults were set before 1504. Although those alterations caused the height of the nave to arise from $14 \mathrm{~m}$ to $22 \mathrm{~m}$, Dominicans remained the chancel arch from the middle of the $13^{\text {th }}$ century which was only around $10 \mathrm{~m}$ in high (Fig. 3a). 


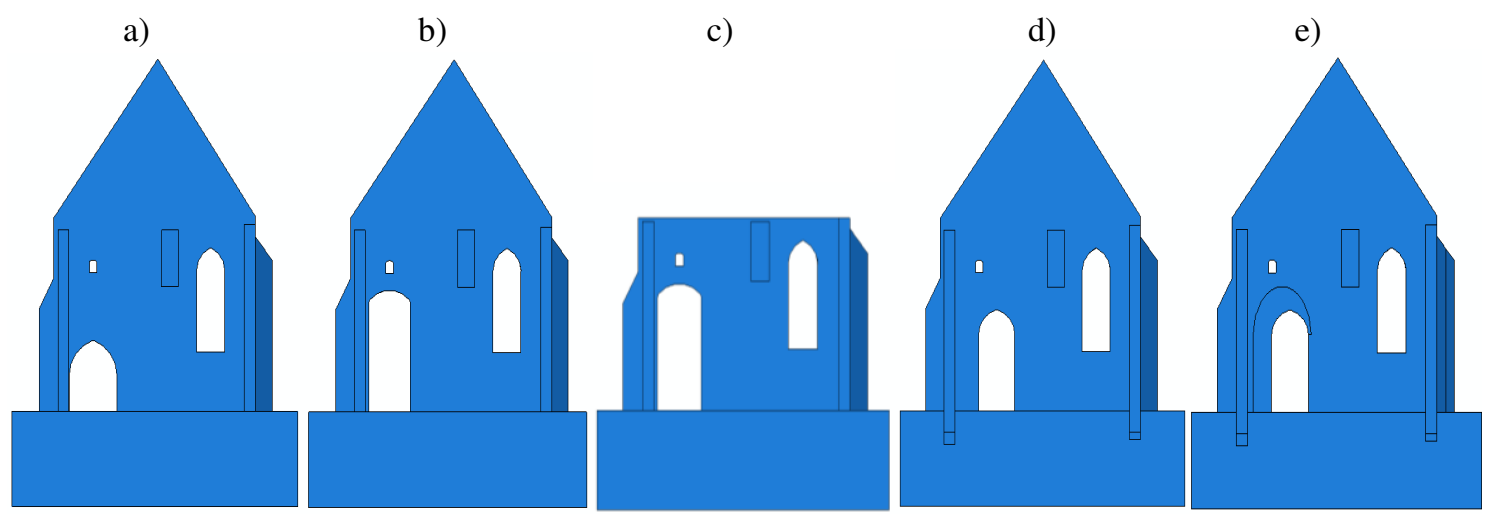

Figure 3. Church wall resting on soil foundation from: a) 1504 b) ca. 1680 , c) 1827 , d-e) after 1880

A decade later, the reformation gained many supporters in Elbląg (as well as in whole northern Poland) which caused the cancelation of the Dominican monastery. The church was taken by the protestants, whose aesthetical beliefs focused on the purity of architecture and its functionalism. Therefore, the new owners had not conducted any important transformations of the church for the next 150 years. In the $17^{\text {th }}$ century new chancel arch was created through the demolition of $8 \mathrm{~m}$ of the wall above the previous one. The new arcade was topped with an elliptic arch, typical for the baroque perjod. The historical sources gave no information why ecclesial administration decided to rebuild this part of the church, It might have been caused by the destruction of the spire and the vaults in the east choir in 1680 223]. However the structural reasons of that damage remained unknown (Fig. 3b) At the beginning of the $19^{\text {th }}$ century Prussian government centralized building administration in the entire state. As an effect of that reform, the former Dominican church

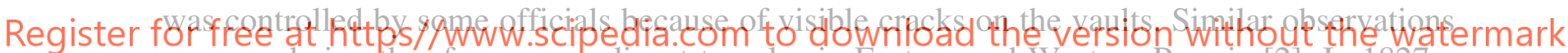
were made in other former mendicant temples in Eastern and Western Prussia [2]. In 1827 a system of supporting construction and removal of the gothic roof was designed, but its realization was delayed and later cancelled [24]. The structural analyses of potential rebuilding described above allowed to evaluate whether the proposed repairs would have been needed and reasonable (Fig. 3c).

In the 1880s the ecclesial administration decided at least to strengthen the cracked walls of the church including baroque chancel arch. In the first step a massif flying buttress across the chancel arch was built, which supported the central part of the eastern wall. Then the space above the flying buttress was filled with modern, fabric-made bricks from Kadny (Imperial brickyard in the neighbourhood of Elblagg) [25]. The last step was creating of a smaller gothicrevival chancel arch, which is preserved to the present day. The partial demolition of the church during the last war (1945) fortunately did not include the eastern wall except for the gable (Fig 3d, 3e).

\section{NUMERICAL ANALYSIS}

The structural analysis of the former Dominican church in Elblagg was prepared for its four stages. The aim of this investigation is to present how the modern, numerical methods of 
structural analysis might be used in research of historic brick buildings, enlarging the knowledge on their past.

The FE calculations were carried out for gable wall of a height about $36.80 \mathrm{~m}$ and width $21.13 \mathrm{~m}$. The wall thickness was $1.25 \mathrm{~m}$. In the numerical model parts of other (perpendicular) walls of width $1.2 \mathrm{~m}$ were included. Four types of the church wall static schemes were considered (Fig.3 a-c, e). In all variants both the church masonry walls, stone foundations and the soil were included in the numerical model. There was a cut made in the soil for the masonry and stone foundations block. The structure was loaded by inertia and by self-weight.

The numerical static analysis was performed by means of non-linear explicit procedure and commercial program [26]. The method is effective for simulation of damage and degradation of masonry structures. The total number of finite elements of type C3D10M used in the analysis was equal 492983 (model 1A - Figs. 3e, 5a), 487602 (model 1B - Figs. 3d, 5a), 259731 (model 2 - Figs. 3c, 5b), 447368 (model 3 - Figs. 3b, 5c) and 454278 (model 4 Figs. 3a, 4, 5d). The finite element size for the church masonry and stone fundament was 250 $\mathrm{mm}$ while for the soil $1000 \mathrm{~mm}$. The damage model based on plastic degradation implemented in Abaqus software program was used for masonry wall. The following soil parameters were assumed [26]: density $2000 \mathrm{~kg} / \mathrm{m}^{3}$, Young modulus $40 \mathrm{MPa}$, Poisson's Ratio 0.2. The stone foundations characteristics were the following: modulus of elasticity 1200 MPa, Poisson's ratio 0.2, density $2000 \mathrm{~kg} / \mathrm{m}^{3}$ (Fig. 5b-d, 6a-c).
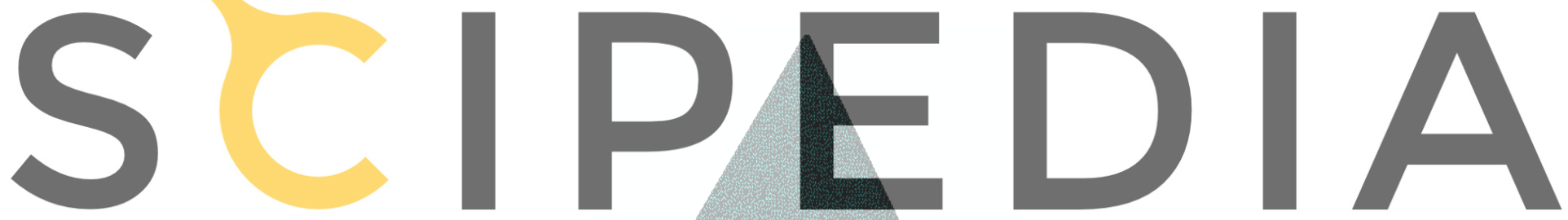

Register for free at https//www.scipedia.com to download the version without the watermark

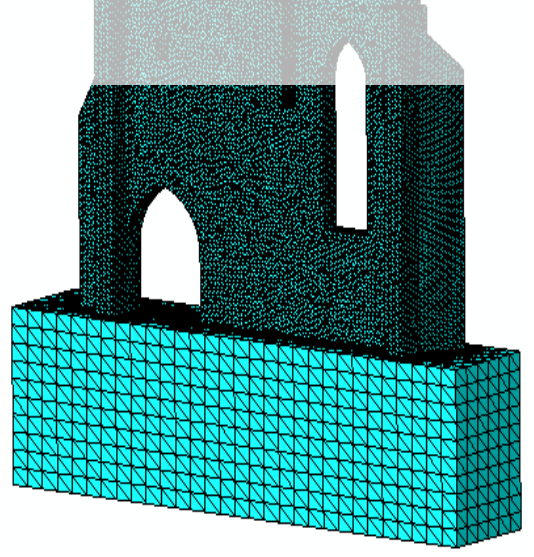

Figure 4: FE mesh of church wall resting on soil foundation from for model 4.

Modulus of elasticity for masonry from Middle Ages was $1910 \mathrm{MPa}$, Poisson's ratio was 0.166 , and masonry density equal $2000 \mathrm{~kg} / \mathrm{m}^{3}$. The parameters of reinforced parts of the 
model (1A - Figs. 3e, 6d) were assumed according to the results of research by Kujawa [14], which was conducted for a similar brick village church situated about $50 \mathrm{~km}$ from the examined temple: modulus of elasticity $7634 \mathrm{MPa}$ Poisson's ratio 0.209 , density $1800 \mathrm{~kg} / \mathrm{m}^{3}$. The damaged model plasticity (CDP) characteristics were: dilation angle 20, eccentricity 0.1 , the ratio of biaxial compressive yield stress to uniaxial compressive yield stress 1.16, the ratio $K$ of the second stress invariant on the tensile meridian to that on the compressive meridian for the yield function 0.667 , viscosity parameter $10^{-6}$.

The displacements of the wall for all considered models are presented in Figs. 5a-d. The maximal displacements of the wall were $86 \mathrm{~mm}$ (model 4), $64 \mathrm{~mm}$ (model 3), $38.5 \mathrm{~mm}$ (model 2) and $31.5 \mathrm{~mm}$ (model 1B), $27.8 \mathrm{~mm}$ (model 1A).

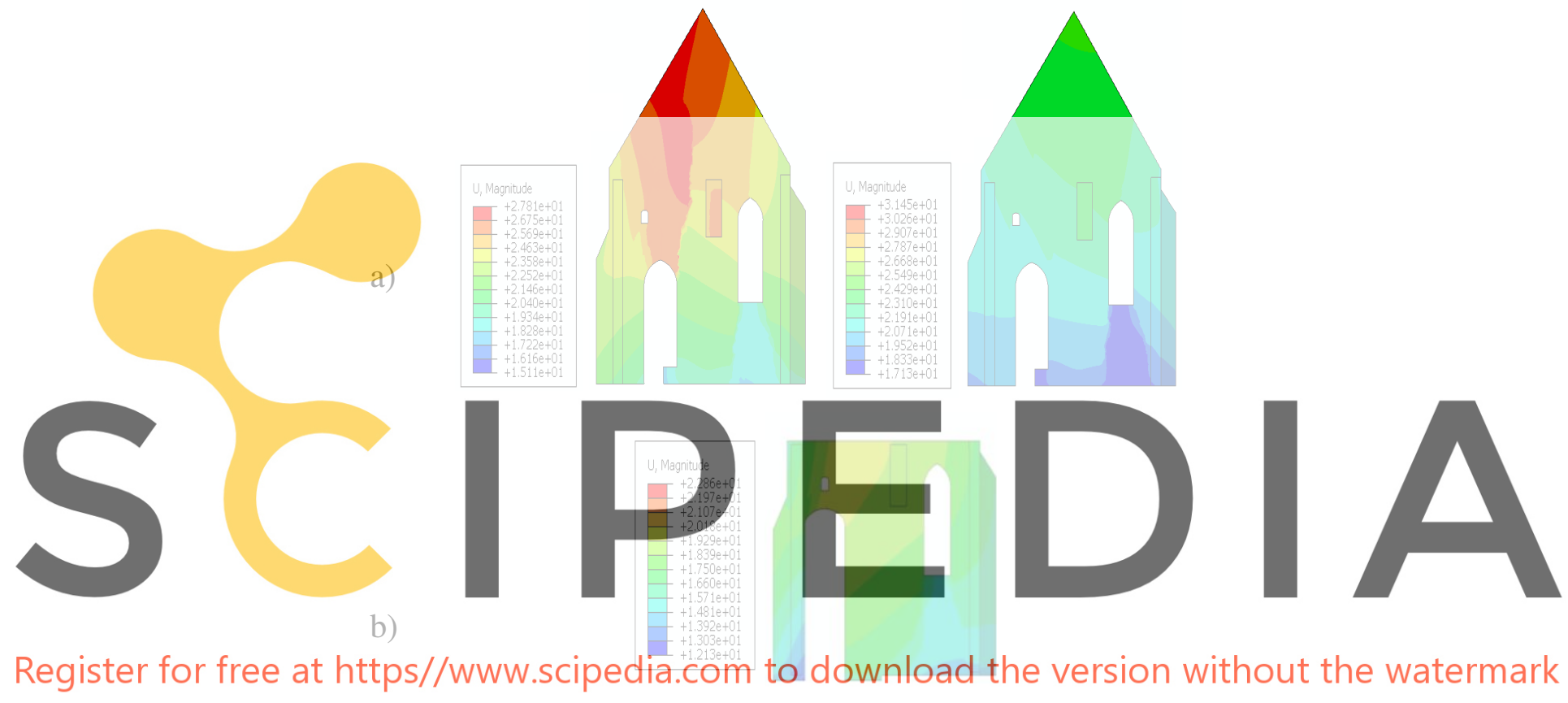

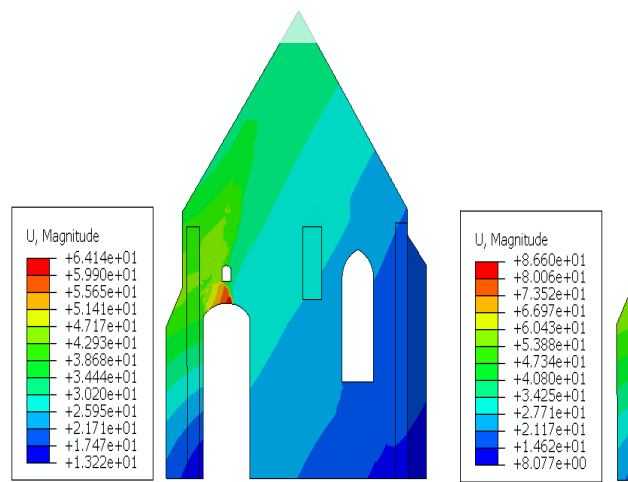

c)

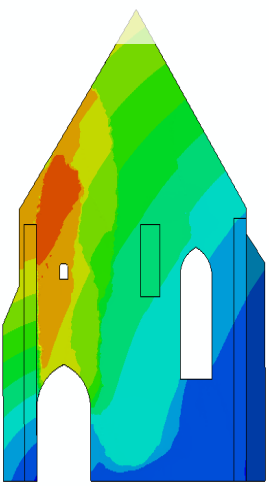

d)

Figure 5: Displacement of church wall for model a) 1A, 1B, b) 2, c) 3, d) 4

The crack propagation for the cases considered is shown in Figs. 6a-d. The main cracks were located above the door and above and under the window and depended on the weight of the masonry. For the case with restrained wall (1B) the cracks were clearly smaller than for 
the original masonry (1A). The results for the tension tests are presented as color maps of equivalent plastic strains in tension (PEEQT). Analysis of material parameters shows that cracks occur for deformations greater than $10^{-3} \times 10^{-3}$.

The first analysis is prepared for the model of the church from the end of the Middle Ages (Figs. 3a, 6a). The form of the triumph arch was created at the turn of $13^{\text {th }} / 14^{\text {th }}$ century and was not transformed during the following medieval building actions, although the height of eastern wall arose from 12 up to $38 \mathrm{~m}$. The structural analysis allowed to recognize the process of damaging the wall through the quadrupled pressure, which was observed in the following centuries (Fig. 6a).
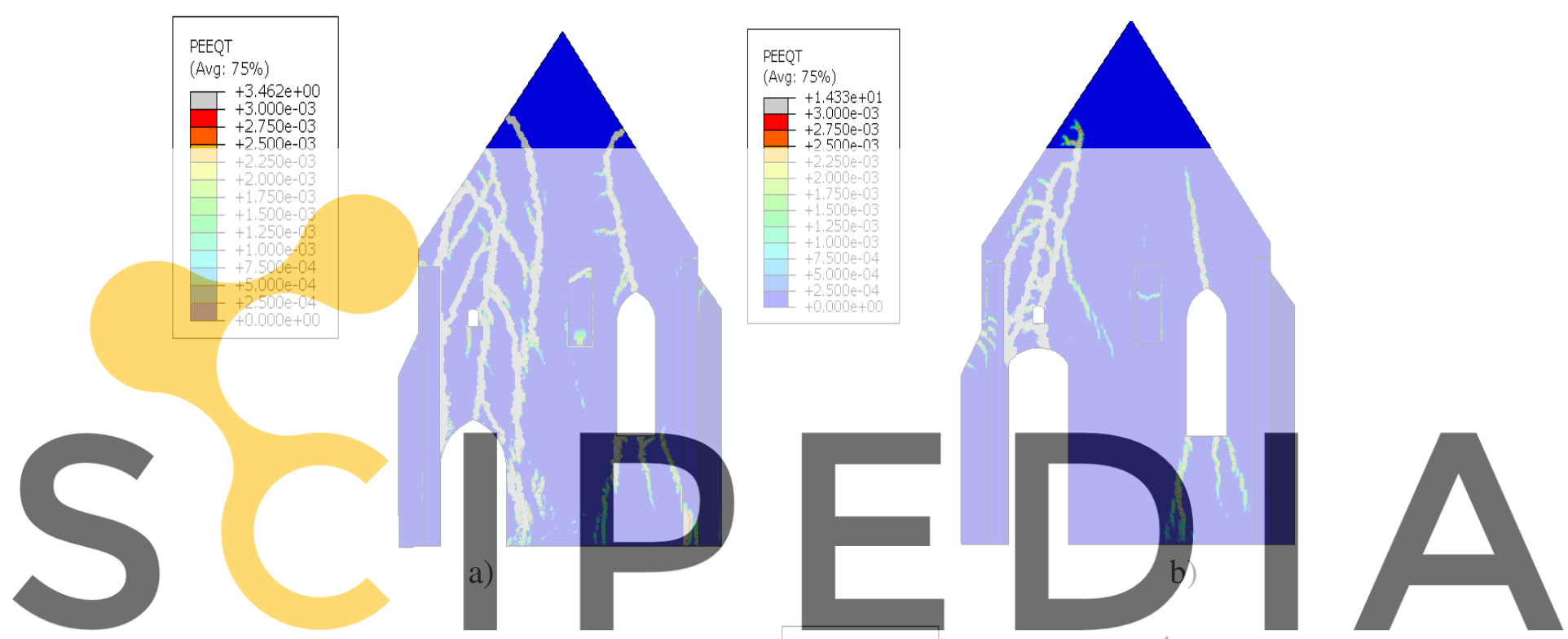

Register for free at https//www.scipedia.com to dowinload the version without the watermark

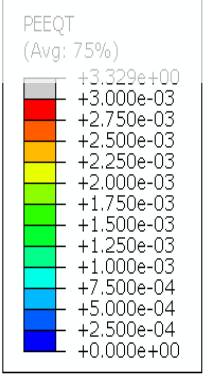

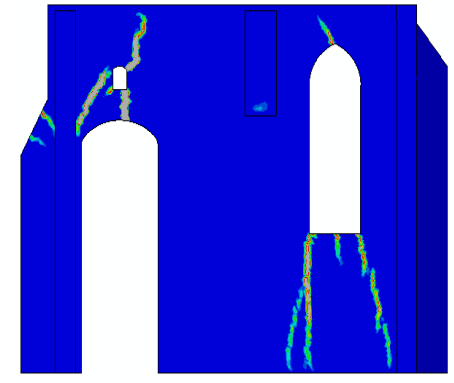

c)

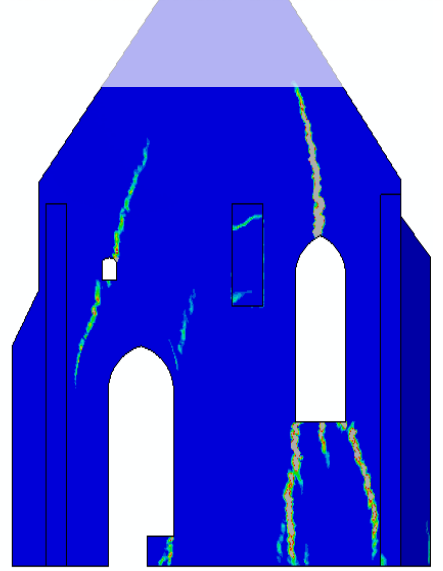

d)

Figure 6: Eastern wall of the church (a - after 1504, b - ca. 1680, c - 1827, d - ca. 1880) with main cracks according to FEM solutions expressed by equivalent plastic strains in tension. 
The second analysis allows to examine the transformation of the church after the collapsing of the spire in 1680 (Figs. 3b, 6b) The falling parts of wooden bell tower destroyed the roof and vaults above the east choir. Although there is no evidence for a coincidence between those events and the rebuilding of the chancel arch, the eastern wall was transformed undoubtedly during that period. Comparing the previous version of the chancel arch with the new one (baroque), allowed to note two issues. The shape of baroque arch is similar to the main cracks above the gothic arch. Thus, the rebuilding of the triumph arch seemed to have been an attempt of its repairing through liquidating the part of the wall directly above the archade, which had been separated from the structure above. It should be mentioned here, that at the turn of the $17^{\text {th }} / 18^{\text {th }}$ century there were no professionals who could interpret the behaviour of structures like engineers in contemporary meaning of this term. Therefore, the structural analysis of the historical transformations may give some additional information on the ability of people back then to react on structural accidents and damages. Descriptions of such actions are often neglected in historical written sources.

The next issue (Figs. 3c, 6c) lets verify whether the project of removal of the eastern gable from 1827 was necessary from the engineering point of view, or whether it was rather an attempt to change the aesthetic value of the church to a more fashionable one. It was remarkable, that the design of urgent repairs was delayed before the ecclesial authorities would finance the construction works. The removing of the gable would have solved the structural problems of the eastern wall but it was also a radical move, changing not only the shape of the church buta

The last analysis may be observed tho the church to survive bricks and mortar was chancel arch.
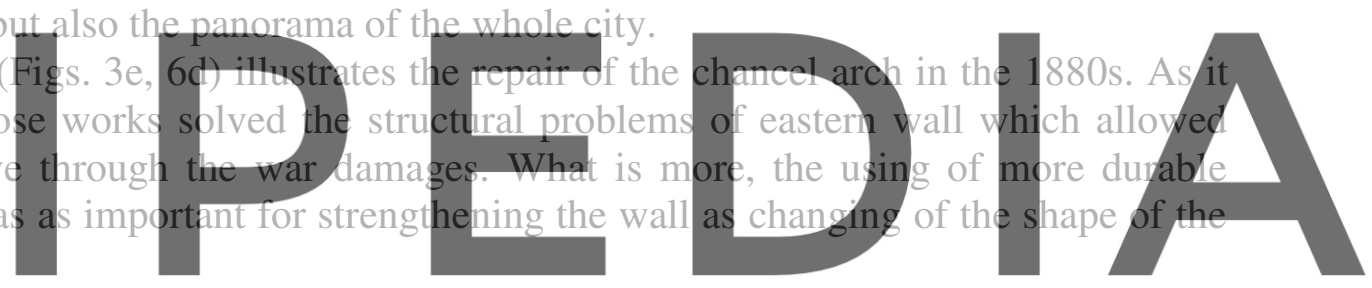

Register fôr free at https/FWWw.scipedia.com to download the version without the watermark Architectural investigations allow to reconstruct the history of the heritage monument, but they are almost always conducted separately from the structural analyses. What is more, most researchers focus on interpreting architects' decisions through the artistic and ideological aspects rather than the pragmatic issues. This scientific method may be observed well particularly in central Europe, where many historical written primary sources were lost. As a result of that, many objective reasons of building actions from the past were neglected. The presented example of Dominican church in Elbląg allows comparing the results of its architectural investigations with the structural analysis of recognized stages of construction. This research gives an opportunity to expand the evidence base and to seek the answer about, why some architectural and engineering solutions were ever adopted. It is obvious that such a research may be conducted only during the traditional architectural examines, because the representatives of different scientific disciplines give and receive a proper feedback then. This is also the reason, why structural analysis has not been used as a supporting method to historical studies on architecture yet.

The authors of this paper expand their research on other monuments (e.g. Franciscan church in Chełmno, Poland), which were created in a multi-stages process. 


\section{ACKNOWLEDGEMENTS}

This paper partially presents results of the research project No. 2017/1/X/HS2/00626 financed by the National Science Centre, Poland.

The numerical calculations were performed using the computing resources of CI TASK at Gdańsk University of Technology.

\section{REFERENCES}

[1] Roca, P., Cervera, M., Gariup, G. and Pela, L. Structural Analysis of Masonry Historical Constructions. Classical and Advanced Approaches, Arch. Comput. Methods Eng. (2010) 17: 299-325.

[2] Samól, P. Architecture of the Dominican Churches in medieval Prussia, Gdansk: [PhD Thesis] (2015).

[3] Godinho, M., Machete, R., Ponte, M., Falcao, A. P., Concalves, A. B. and Bento R BIM as a resource in heritage management: An application for the National Palace of Sintra, Portugal, Journal of Cultural Heritage, in print (2020).

[4] Dall'Asta, A., Leoni, G., Meschini, A., Petrucci, E. and Zona, A., Integrated approach for seismic vulnerability analysis of historic massive defensive structures, Journal of Cultural Heritage (2019) 35: 86-98.

[5] Groat, L. and Wang, D. Architectural research methods, Wiley (2013).

[6]Lourenço, P.B. Analysis of historical constructions: From thrust-lines to advanced simulations. In: Lourenço P.B., Roca P. (Eds.): Historical Constructions, Guimarães, (2001): 91-116.

[7] Lourenço, P.B. Computations of historical masonry constructions. Prog. Struct. Engng. Mater. (2002) 4/3: 301-319.

[8] Roca, P., Cervera, M., Gariup, G. and Pela, L. Structural Analysis of Masonry Historical Constructions. Classical and Advanced Approaches. Archives of Computational Methods in Engineering (2010) 17: 299-325.

[9] Theodossopoulos, D. and Sinha, B. A review of analytical methods in the current design processes and assessment of performance of masonry structures. Construction and Building Materials (2013) 41: 990-1001.

[10] Giordano, A., Mele, E. and De Luca, A. Modelling of historical masonry structures: comparison of different approaches through a case study. Engineering Structures (2002) 24: 1057-1069.

[11] Lubliner, J., Oliver, J., Oller, S. and Oñate E. A plastic-damage model for concrete. Int. J. Solids Struct. (1989) 3: 299-326.

[12] Resta, M., Fiore, A. and Monaco, P. Non-Linear Finite Element Analysis of Masonry Towers by Adopting the Damage Plasticity Constitutive Model. Advances in Structural Engineering (2013) 16(5): 791-803.

[13] Liberatore, D., Addessi, D. and Sangirardi, M. Nonlinear Analysis of Masonry Walls Based on a Damage-Plastic Formulation. Structural Analysis of Historical Constructions (2019), 18: 1009-1017.

[14] Kujawa, M., Lubowiecka, I. and Szymczak, C. Finite element modelling of a historic church structure in the context of a masonry damage analysis. Engineering Failure Analysis 
(2020) 107: 104233.

[15] Kerisel, J. Old Structures in Relation to Soil Conditions. Geotechnique (1975) 25: 433483.

[16] Przewłócki, J., Dardzińska, I. and Świniański, J. Review of historical buildings’ foundations. Geotchnique (2005) 55: 363-372.

[17] Przewłócki, J. and Zielinska, M., Analysis of the Behavior of Foundations of Historical Buildings. Proc. Eng. (2016) 161: 362-367.

[18] Przewłócki, J., Zielińska, M. and Grębowski, K. Numerical modelling of connections between stones in foundations of histrical buildings, WMESS, IOP Conf. Series, Earth and Environmental Science (2017), 95.

[19] Samól, P. Pierwsze oratorium dominikanów w Elblągu z połowy XIII wieku [=First Dominican chapel in Elbląg from the half of the $13^{\text {th }}$ century], In: D. Stryniak, T. Janiak [Eds.]: Architektura skralna w średniowiecznej Polsce, Gniezno (2016): 543-554

[20] Gajewska, M. and Kruppe, J. Badania archeologiczne na terenie kościoła NMP w Elblaggu w roku 1959 [=Archaeological excavations in the area of Our Virgin Lady church in Elbląg in 1959], Rocznik Elblaski (1959) 1: 207-226.

[21] Archive of Contemporary Art Centre "Galeria EL" in Elbląg: report of Gołembnik, A. Sprawozdanie z badań archeologicznych $w$ obrębie podominikańskiego kościoła p.w.

Najświętszej Panny Marii. Centrum Sztuki Galeria EL [=Archaeological excavation inside the former Dominican church of Our Virgin Lady - Contemporary Art Centre "Galeria EL"] Elbląg (2008).

[22] Piwek, A. Kościoly gotyckie o układzie pośrednim (pseudohala, pseudobazylika) w Polsce [=Gothic churches built as pseudobasilicas in Poland], Gdańsk [PhD Thesis] (1996). [23] Fuchs, M. G. Ein Schulactus auf dem Elbinger Gymnasio den 14ten April 1796 zum Andenken der Gründung der Hauptkirche zu St. Marien in Elbing vor 550 Jahren gehalten, Elbing (1796).

[24] State Archive in Gdansk, acts no. 300, 1151/192.

[25] Hauke, K. and Stobbe, H. Die Baugeschichte und die Baudenkmäler der Stadt Elbing, Stuttgart (1964).

[26] ABAQUS, Theory Manual, Version 6.8, Hibbit, Karlsson \& Sorensen Inc, (2008) 